\title{
Erasmus and István Magyari on the Justification of War ${ }^{1}$
}

\author{
Mihály BODA²
}

\begin{abstract}
Warfare ideologies in Europe basically changed in the Early Modern period. This period is the age of Reformation, of which Desiderius Erasmus was one of the earliest prominent thinkers. Concerning warfare, Erasmus can be understood as a representative of pacifism, but at the same time, it can be argued that he was the first reformer with a specific theory of justification of war. In this respect, Erasmus had several followers from every part of Europe, including Hungary. This Hungarian "apprentice" was István Magyari, who was also the first representative of Hungarian military science. This paper uncovers and examines the common points of Erasmus and Magyari in their theory of justification of war, and Magyari's divergence from Erasmus' thinking.
\end{abstract}

Keywords: justification of war, just war theory, Erasmus, István Magyari

\section{Introduction: Just War Theory in the Middle Ages}

In order to examine reformers' warfare ideologies I will build on a specific theory, the just war theory in the form crystallised and systematised by the $13^{\text {th }}$ century by Thomas Aquinas. [1: 171-177] Although, this theory is characteristically Catholic in its content, I can set aside this Catholic content and focus exclusively on the formal features of the theory. The reformers themselves knew and employed the same features within the framework of the theory without accepting the claims of Thomas Aquinas or other Catholic thinkers.

The formal features, steady-state by the period of the reformers (by the turn of $15^{\text {th }}-16^{\text {th }}$ centuries), are the following: the thinkers of the Early Modern period more or less accepted that there is significant difference between the lawfulness of initiating a war on the one hand, and the lawfulness of waging a war on the other hand. Since the middle of the $20^{\text {th }}$ century specific terms-ius ad bellum and ius in bello-have been applied for these forms of justice. Thomas Aquinas listed three rules as ius ad bellum rules: the rule of legitimate authority, according to which only the prince was authorised to initiate war; the rule of just cause, according to which war is permitted to initiate only for punishing the breakers of peace and hence to defend peace; and the rule of right intention. The latter rule has two interpretations for Aquinas, the first concerns the extension of Christian peace as the further

This paper was supported by the János Bolyai Research Scholarship of the Hungarian Academy of Sciences. Ph.D., associate professor, University of Public Service; e-mail: Boda.Mihaly@uni-nke.hu; ORCID: https:// orcid.org/0000-0003-3037-3644 
purpose of war, and the second considers the right intention rule as the rule of waging a war with charity (and not, for example, hatred or anger). Only the former interpretation of the right intention rule fits into the requirements of ius ad bellum, the latter one is a rule of ius in bello.

\section{Erasmus on the Justification of War}

Many different standpoints can be supported on the question "What is the moral value of war in general?" One is the theory of realism, according to which war is good as a tool if it helps to satisfy the interest of the state. A completely different point of view is pacifism, according to which war cannot be good at all, because it always goes hand in hand with several deaths and serious suffering of human beings. Erasmus, contrary to his contemporaries Machiavelli and Gentili, is often shown as a representative of pacifism; his work principally referred to is Dulce bellum inexpertis (Against war, 1515). [2] However, the content of Erasmus' other works suggests a not completely pacifist standpoint, because these works take the point of view of justifying defensive and offensive wars.

Erasmus deals with the problem of justification of war in detail in his Querela pacis (A Complaint of Peace, 1517), [3] Consultatio de bello turcico (On the War against the Turks, 1530), [4] and Institutio principis christiani (The Education of a Christian Prince, 1532). [5] In justifying war he draws a distinction between defensive and offensive wars on the one hand, and between wars of one Christian prince against another, or the wars of Christian prince(s) against non-Christians, on the other hand. Erasmus takes defensive wars justified if the just cause is the protection of the community against another Christian prince (which is a form of law enforcement), or against a non-Christian prince - actually against the Turks (which is defending Christianity. [3: 314] The ideas in both cases are based on the argument that the prince serving the Christian peace and community has the right to punish those who committed something wrong against the community, and hence he has the right to defend the community against internal and external dangers, which one can find in Aquinas as well. [6: 221-224] Erasmus, however, dealt much more with the frameworks of justifying offensive wars than defensive ones. In the following I examine Erasmus' ideas on offensive war between Christian princes, and between Christian and non-Christian princes.

Erasmus, starting from the practice of his contemporary princes' wars against each other, and the humanist warfare ideologies, considers that wars of Christian princes against each other are totally unacceptable and forbidden. What was the specific princely ability of virtus with the objective of satisfying interest of the state, was for the humanist thinkers the example of princely ambition and satisfaction of princely self-interest. Erasmus writes: "One [prince] discovers or invents some mouldering, obsolete title to support his claim [...] Another pleads some trifling omission in a treaty covering a hundred clauses, or has a personal grievance against his neighbour over the interpretation of an intended spouse or a careless word of slander. Most criminally wicked of all, there are rulers who believe that their authority is undermined by harmony amongst their people and strengthened by discord, so they use their despotic power to suborn persons who will set about stirring up war; [...] There the worst sort of criminals, men who thrive on the sufferings of the people, and in time of peace find little to do in society.” [3: 305-306] 
That is, princes do not have any worthy aims for which one is morally permitted to unleash a war. Erasmus, setting aside this problem, emphasises that breaking peace in accordance with any_-just or unjust_cause or aim has very serious consequences. In the opening paragraph of A Complaint of Peace, the "Peace" complains that men take peace as a source of every human happiness, but contrary to this, princes too easily turn to war, which "is a kind of encircling ocean of all the evils in the world". [3: 293] War is basically antihuman for two reasons: because it is contrary to human nature, and because it destroys human civilisations built up in peace.

According to Erasmus, independently of how we define human essence, taking men as members of nature, or subjects of Christ, war in both cases is contrary to human essence. In nature, harmony characterises the relationships within the species of wild animals, and of the planets, so men, too, should live in harmony with each other. Men, with the help of their naturally given reason, can understand that their essence predestined them to lead a peaceful life based on agreement. Nature did not give to human beings abilities (natural weapons) by which they can manage their life alone, but from the very beginning of their life, they are in the need of help. [3: 294-296]

We should draw the same conclusion from the supposition that men's Christian features are more important than their natural endowments. Since Jesus Christ is the prince of peace, and the Christian God is god of peace, the purpose of Christian princes should be to live in a Christian way, and to build and sustain the peace in their countries and in the relations with their potential enemies. [3: 299] Hence, the further aim of every truly Christian politics is to establish the communion of every Christian men and to progress on the way to the eternal salvation and immortality, which is the "indescribable communion of happy spirits”. [3: 320]

Therefore, war is antihuman in nature for it is contradictory with the essence of men, and for another reason, too: war demolishes the fruits of peace. However, the purposes of wars are the princes' selfish purposes, every devastating consequences of wars are incumbent on the people and the country. War demolishes the laws, inner discipline and religious purity of citizens, moral chastity of the country, and the villages, the cities and the temples; it makes the fields of the country being desolated, and releases crimes and outrage of mercenaries in the country. [3: 316-317] According to Erasmus, these consequences are independent of the prince's moral stance, or of the just or unjust nature of the cause of war. The "war is by its nature such a plague to man [...] results in almost more evil than good”. [4: 318]

According to Erasmus, wars between Christian princes have only natural causesfoolishness, anger and ambition-, [3: 305, 310] and never have just causes. It is a real possibility, however, for the prince to consider whether he should initiate a war or not. In this consideration, the prince should take into account such features, according to Erasmus, which did not gain much attendance in the Middle Ages. These features are the modified rule of legitimate authority, the rules of proportionality, of last resort, of reasonable chance of success, of declaration, which the previously already acknowledged rule of right intention joins. These rules constitute the rules of the Erasmian ius ad bellum of offensive war, with the absence of the rule of just cause. These two conditions, i.e. the lack of the just cause and the presence of other rules, show that war is always wrong from moral point of view (because war never has a just cause); some wars, however, can be justified as "lesser evil" (because rules other than just cause can morally vindicate them). 
A part of these rules, particularly the rules of extended legitimate authority, of proportionality, of last resort, and of declaration, became important in the Early Modern period for Erasmus and for others, because the religious justification of war receded by that time. While the content of the just cause was defined with the help of purposes, commands, and intentions of God, these other rules were relatively uninteresting, because God's aims are incomparable with human casualties, so the war could not be for example disproportional. Since, however, causes of war were redefined in terms of human purposes, the prince should have made good decisions with the help of the potentially affected people, and by comparing the alternative ways of conflict management.

With the help of the rule of legitimate authority, Erasmus wants to emphasise that a Christian prince should consider the possibilities and make a wise decision before he initiates a war, and the prince should not pay attention to his passions. That means, Erasmus supposes that the prince has the right to start a war, [3: 282-288] however, he acknowledges the limits of this right as well. The prince should ground his decision on the wise advice of those who are old enough to give advice (because younger people usually like the idea of war), who are respected by the common people, but who are not interested in the turmoil caused by war. [3: 313]

Erasmus gives another restriction of legitimate authority with the rule of declaration. He thinks the causes of war should be made public immediately in order that perhaps somebody can give an "excuse” for avoiding war. [3: 313] The wise advice or the excuse coming from the advisers or the common people are in connection with the loss and gain of the war and so the general rule of proportionality of ius ad bellum.

The rule of general proportionality includes three different rules. These are the rules of reasonable chance of success, of last resort, and of particular proportionality. All these rules contain some element of proportionality, so the prince and his advisors considering them should think about the following: whether the purpose of war can be reached at all or there is no chance; if it can, then whether it can be reached only by war or by other, more peaceful means, too, which results in less losses; and if not, then whether the suffering brought about by war is proportional to the positive value of the cause of war (whether it results in more good than bad consequences, supposing the success).

The rule of reasonable chance of success requires the prince and the advisors to consider the possible ends of the war before the attack, and whether the reasonable possibility of winning the war exists or not. [5: 282-283] If one cannot suppose such a possibility in a reasonable way then the war can be heroic or self-sacrificing, but it cannot be justified because there are not any good consequences over against the caused suffering and deaths, it is extremely disproportional.

The rule of last resort demands the prince and his advisors to take into consideration all the means which can be applied in conflict management, by which the war can be avoided, and not just the possibility of war. Erasmus mentions two such alternative possibilities: appointing arbiters, [3: 310-311] and buying the peace. [3: 313] By considering these possibilities, the prince and the advisors should compare the good and bad consequences of these possibilities with those of war. For example, thinking about buying the peace for a sum of money should be taken into account (the former is the gain and the latter is the loss for the country), and the good and bad consequences of buying the supposedly successful war expressed in a specific sum of money, which sum may be more advantageous to be chosen. 
The rule of particular proportionality has its own significance, because it requires the prince to think about and compare the good and bad consequences of bringing about the war. According to Erasmus, the bad consequences affecting the people who do not have influence on starting the war (the peasants and the poor) should be weighted. [3: 312] One extreme case can be that in which there is no chance to attain the purpose of the war, because in this war even a minimal loss makes the war disproportionate.

Finally, before initiating a war, the prince and his advisors should consider the further purpose of war which can be reached by the war. This is the rule of right intention, which has a very specific position in the theory of Erasmus. Since the purpose of Christian princes cannot be other than to build and sustain the empire of Christ and peace in the created world, Christian princes are not morally permitted to wage a war against each other. The rule of just cause is missing from Erasmus' theory for this reason, due to the Christian rules of right intention.

Offensive wars against non-Christians, however, constitute another sort of wars, because according to Erasmus, Christian princes are morally permitted to start a war against nonChristians, particularly the Turks. What is the reason for initiating a war against the Turks? Erasmus writes: "But perhaps it is the fatal malady of human nature to be quite unable to carry on without wars. If so, why is this evil passion not let loose upon the Turks? Of course it used to be thought preferable, even in their case, to win them over to the religion of Christ by teaching and by the example of good deeds and a blameless life rather than by mounting an armed attack. But if war, as we said, is not wholly avoidable, that kind would be a lesser evil than the present unholy conflicts and clashes between Christians.” [3: 314]

At first sight, this text takes conflicts, and wars specifically, as an integral part of human life, and perhaps Erasmus thinks that wars are unavoidable, so wars should be started against the Turks and not against other Christian princes.

However, some arguments can be put forward against this interpretation. We saw earlier how Erasmus defines the nature of human beings with the help of the concepts of harmony, cooperation, and peace. This definition does not include conflict and war as natural phenomena, so the above text cannot be interpreted contrary to this.

Furthermore, I mentioned above that according to Erasmus the princes in fact initiate wars for their self-interested purposes, for example, when a prince behaving as a tyrant unleashes a war to keep his subjects busy. Erasmus condemns this practice and such cause of war. On the basis of the cited text Erasmus may be supposed to suggest something similar to exhorting against the Turks. I do not think so.

The text, I claim, should be interpreted in the light of Erasmus' specific view on the Turks. According to Erasmus the Turks are more inferior people than Christians. Turks are naturally lovers of luxury, and for this reason self-indulgent people, who are inclined to robbing lifestyle (for taking others' property arbitrarily), to avarice, envy, ambitiousness, greed for power, anger, and hatred. [3: 324] However, Turks are still better and more superior than Jews and black Africans, because Turks in their religious believes are close to Christians, so they are "half-Christians". [3: 317; 7]

For this reason it can be supposed that Erasmus exhorts for an offensive religious war against the Turks for conversion, which war would be a "lesser evil". I think the cited text of A Complaint of Peace can be explained in this way. This interpretation is supported by another work of Erasmus, On the War against the Turks. 
According to Erasmus, there are preconditions for conversion. The conversion of the Turks to Christianity can be successful if Christians take Christianity seriously, practice it and set an example for Christian life to the Turks. Conversion can be successful in this case only. Of course, it is possible that the princes of the Turks do not want to respect Christianity and resist to peaceful conversion. This time Christians can convert the Turks to Christianity by force. But for Erasmus, peaceful attempt of conversion is a precondition of forced conversion, which in this way can be initiated as last resort.

Erasmus writes in 1530, after the Turkish siege of Vienna in 1529: "It is no longer a case of sharing these disasters because of our common religion, but because there is a danger now that we may soon share them in reality. 'When your neighbour's wall is in fire it becomes your business'; in fact, it becomes the business of the whole city, whenever a single house catches fire. Therefore we must give assistance if we are truly anxious to rid ourselves of this peril; but assistance of two kinds. Of course, we must make all the preparations necessary for such an arduous war, but before that we must make the preparations without which military strength will be in vain.” [4: 316]

Christians, for initiating war, need military preparation; for military preparation, however, they need to be prepared in faith. Preparation in faith means taking seriously, purifying and reforming the practice of religion, and together with this, settling the conflicts of Christian princes. In A Complaint of Peace Erasmus supports this claim by demanding reform of the practice of religion as a necessary condition of peaceful conversion. In On the War against the Turks he argues on another track. The change in the argument is due to the changes in the political circumstances of his time: the Turks defeated the Hungarian king on the battlefield in 1526, and then sieged Vienna in 1529.

According to the second argument, the cause of the successes of the Turks, for example that they reached the capital of the Habsburg Empire, is the sins of the Christians, and not the Turks themselves. God punished Christians for their inner conflicts by having allowed the Turks to win over the Christian armies. [4: 316-317] Hence, the military preparedness alone is not enough against the Turks. If it is not complemented with preparedness in faith, then the Turks will defeat the Christian army again. Therefore reforming the practice of religion is a necessary condition of the successful fight against the Turks, and at the same time the necessary condition of their (peaceful or forced) conversion. By this, the rule of right intention can be completed as well. [4: 324]

To sum up Erasmus' position on the problem of justifying an offensive war we can state that the starting point of Erasmus is the understanding of the concept of Christian peace, and that this peace should be secured in Europe among the Christian princes, and as far as possible, in the Ottoman Empire as well. Erasmus accepts the "just war" position of his predecessors regarding defensive wars, but he determines new claims concerning one part of offensive wars. Referring to the wars among Christian princes, Erasmus emphasises that wars are unjust and so cannot have just causes, but can be morally permitted under other rules, so wars can be justified as a "lesser evil". The other part of offensive wars are the wars of conversion whose justification depends on whether Christians can suit themselves to the principles of Christianity by living a peaceful life, setting an example of Christian life to the Turks. If this example does not have any outcome on the side of the Turks, then, as a last resort, Erasmus regards offensive wars of conversion against the Turks morally acceptable. 


\section{Erasmian Elements in István Magyari’s Theory of Justification of War}

István Magyari (1565-1605) was a Hungarian military scientist, baron Ferenc Nádasdy’s court chaplain, then deacon in Sárvár (Hungary), who dealt with the problem of justification of war in his book Az országokban való sok romlásoknak okairól (1602, On the causes of the many decays of the countries). One can find in the focus of his book the idea that the attack and success of the Turks (in Hungary in the $16^{\text {th }}$ century) are God's punishment on the Christians for their sins. According to Magyari these sins are the clear consequences of the Catholic lifestyle, among others idolatry. Magyari lists protractedly the examples of Catholic idolatry, like respecting molded and carved pictures, reclusory, nunship, specific masses, clothes of priests, or the ostentatiously furnitured temples. [8: 32-33] Magyari, however, has the remedy for the decays of the country, on which he writes in the fourth chapter of his book.

Considering the nature of the remedy for decays, Magyari is a disciple of Erasmus: he refers to Erasmus expressis verbis, and the structure of Magyari's book is similar to that of A Complaint of Peace. Apart from the many similarities, however, there are some differences as well.

Magyari thinks that the promotion of selfish aims is the main motivation of warfare in his age, by which hence princes do not intend to protect the common good of the community. Since the good of the community has greater value than selfishness and it can be promoted first of all in peace, Magyari condemns warfare. [8: 154, 157] The condemnable character of war emanates from the nature of human beings, and the harms caused by wars.

According to Magyari, God created human beings for fellowship, which can be seen from the fact that men, similarly to wild animals, do not have natural weapons. Men are naked, without weapons, and so helpless, unless they receive assistance from others. [8: 157] This one train of thought includes Erasmus' ideas on the natural and Christian essences of men together. As far as the harms caused by war are concerned, Magyari thinks laws lapse in war, so the extent of unlawfulness increases, and people and their property decay. The community suffers a lot of harms, and becomes impoverished. [8: 158-159)]

So far Magyari has strictly followed the ideas of Erasmus, however, here he comes to the discussion of the just and unjust causes of war and takes the position of just war theory, in which he somewhat dissents from the point of view of Erasmus. [8: 153]

Magyari defines just causes indirectly, by defining the cases of unjust causes: it is unjust if the prince initiates a war but does not defend the faith or the country, or does not help the neighbor to defend his country. [5: 159] This implies the just causes of war, which is called by Magyari “worthy” and "necessary” causes, namely defending the Christian faith, defending one's own country, or helping to defend the neighbouring country.

Just and "necessary" causes include principally the self-defence of a community (the Christian community, or the country), or as it is said nowadays, the protection of the rights of the community. This perspective on just war theory is very different from the medieval form of the theory, according to which just wars are first of all a form of law enforcement and not right-protection. Therefore, Magyari dissents from Erasmus' theory of justifying defensive wars, because Erasmus grounds his theory on the medieval theories (primarily the theory of Thomas Aquinas). 
Comparing Magyari's list of just causes to that of Erasmus, the lack of offensive causes is conspicuous, first of all the conversion of the Turks. This is because while Erasmus wrote at the beginning of the $16^{\text {th }}$ century when the Turks had just conquered a great part of Hungary, Magyari worked at the end of that century, during the Fifteen Years War (or Long Turkish war) (1591-1606). This war had escalated from skirmishing activities on both sides, and developed to a defensive war of the Habsburg Monarchy. So, the corresponding warfare ideology was not offensive, e.g. converting the Turks, but a defensive one.

According to Magyari, the prince has legitimate authority: that is the right and duty of the prince to consider the justness of the causes. However, the prince should represent his people. Magyari compares Hungarians to the Jews with the help of the texts of the Bible and the Old Testament. He thinks Hungarians are God's chosen people, like the Jews were, who are now being punished by the Turks. The purpose of punishment is to redirect the chosen people to the right way of faith, so to give up idolatry. [8: 138-139] At the same time Magyari finds it important to follow the examples of the past pagan and Christian kings, too [8: 124], to the extent it is not in contradiction with the commands of God. People must not follow that rule of the kings which contradicts to the commands of God. [8: 140]

If a prince has a just cause to initiate a war, namely to defend the faith or country, then the prince is supposed to consider the consequences of war, namely the harms possibly caused by the war. If the harm is much more compared to the just purpose of the war, then the war must not begin. This rule is the rule of general proportionality of ius ad bellum. [8: 159] Magyari, unlike Erasmus, does not discern the different forms of the general rule, the rules of the reasonable chance of success, of last resort, and of particular proportionality.

If the war has a just cause and it is proportional, too, then it is important for the prince to initiate the war with the intention defined by the just cause. Magyari forbids those wars which are grounded on envy, pride, hatred, conceit, or are waged for glory, wealth, or building an empire. He takes crusades, the offensive war for conversion, against the Turks as such wars. [8: 159] This sort of the rule of right intention includes the form which is mentioned by Thomas Aquinas, namely, Christian soldiers should fight against the enemy with charity, for the salvation of the enemies. This rule was a ius in bello rule in the Middle Ages, and the purpose was to secure a possibility for the Christians to be soldiers. In Magyari's theory this rule gets a new interpretation, and becomes a ius ad bellum rule, according to which the content of the prince's intention to initiate a war should suit to the content of the just cause. To put it in another way: a just war should be waged without ulterior motives.

The other form of medieval rule of right intention is that initiating a just war, the prince needs a peace conception which includes the enemy who will be defeated; this, as a further purpose, is prescribed by Magyari as well. The proper peace conception for him is characterised by the absence of Catholic ("papist") idolatry, and it is the peace which returns to the direct respect of God, the peace of "Jewish Christianity". [8: 138-13]

Magyari, like Erasmus, does not have much to say on the rules of waging war, ius in bello, because both thinkers understand war as bringing about demolishing consequences. However, Magyari mentions a specific subject, the problem of preparing for a just war: before the prince initiates a war, he needs to build an army by which he can have 
a just fight with chance against the enemy. The just building and training of this army is called ius ante bellum in our age.

According to Magyari, four sorts of rules should be taken into account in ius ante bellum: the rules of everyday life of soldiers (which result in a specific soldiers' ethics); the rules of restoring and maintaining the valour of warriors; the rules of supporting the elements of artificial courage (which are the major part of soldiers' ethics); and finally the rules of civil-military relations of that age (which are needed regarding the differences between the "old"civil ethics and the new military ethics).

Based on these sorts of rules, the armed forces should be built in a way that its soldiers should have "proper discipline", which prevents them from wandering about at their will. [8: 133] Hence, soldiers are supposed to live in barracks in order not to disturb the peace of civilians by their wandering, robberies, and ravaging. In the barracks the soldiers should be satisfied by relatively little food and drink, and they should practice themselves in their profession, discipline (together with artificial courage, [9: 23-24] the swiftness, and the abilities of leadership). The maintenance of the barracks should not be charged financially or otherwise on the civil society, because it would lead to dissention between the army and civil society. Soldiers, however, should be paid every time, so that they could sustain themselves and do their tasks. The military pay or the failure of the pay shows clearly whether soldiers are honoured or not. For maintaining or restoring the honour of soldiers the armed forces need to be standing, rather than hiring every applicants in necessity, who are often quite inexpert. This is because these latter soldiers react negatively to the properly trained and honoured soldiers, too. For a similar reason it is important to care about the wounded or killed soldiers, who risked their lives for the country. [8: 160-173]

To sum up Magyari's theory of justification of war one can state that for him Erasmus shaped the course, but his theory has independent parts as well. Magyari's theory is a form of just war theory, whose key points are the legitimate authority restricted by the representative function of the prince; the just causes for initiating a war for defending Christian faith, the issue of own country and neighbouring country; the modern form of the rule of right intention; the rules of proportionality and right intention of his age; and last but not least, the rules of ius ante bellum.

\section{Conclusion}

Hungary found itself in the middle of the Europe-related events from the $15^{\text {th }}$ to the $17^{\text {th }}$ centuries. These centuries were the years of the Turkish conquest and the danger for Hungary and Europe. For this reason, in both Europe and Hungary several thinkers conceptualised the justification of war against the Turks. The Hungarian authors took over the European patterns of thought, like humanism, Reformation, or the ideas of Jesuits, however, in many cases they altered or completed the received ideas. One example of this process is István Magyari’s book Az országokban való sok romlásoknak okairól (1602, On the causes of the many decays of the countries). The ideas of this book are mainly from the European reformer Erasmus, but Magyari adapted Erasmus’ ideas to his own age and to the specific situation of Hungary. By this Magyari built a specific theory of just war, which 
M. BODA: Erasmus and István Magyari on the Justification of War

has its own place in the development of warfare ideologies in the Early Modern period of Hungary and Europe.

\section{References}

[1] AQUINAS, T.: The Summa Theologiae II/II. q. 40. In REICHBERG, G. - SYSE, M. H. - BEGBY, E. eds.: The Ethics of War: Classic and Contemporary Readings. Malden, Blackwell Publishing, 2013.

[2] ERASMUS, D.: Against War. Boston, The Merrymount Press, 1907.

[3] ERASMUS, D.: A Complaint of Peace. In. LEVI, A. H. T, ed.: Collected Works of Erasmus Vol. 27-28. Toronto-Buffalo-London, University of Toronto Press, 1986.

[4] ERASMUS, D.: On the War against the Turks. In. RUMMEL, E. ed.: The Erasmus Reader. Toronto, University of Toronto Press, 1990.

[5] ERASMUS, D.: The Education of a Christian Prince. In. LEVI, A. H. T. ed.: Collected Works of Erasmus Vol. 27-28. Toronto-Buffalo-London, University of Toronto Press, 1986.

[6] FERNÁNDEZ, J. A.: Erasmus on the Just War. Journal of the History of Ideas, 342 (1973), 209-226. DOI: https://doi.org/10.2307/2708726

[7] RON, N.: Erasmus' ethological hierarchy of peoples and races. History of European Ideas, 448 (2018), 1063-1075. DOI: https://doi.org/10.1080/01916599.2018.1485002

[8] MAGYARI I.: Az országokban való sok romlásoknak okairól. Budapest, Magyar Helikon, 1978.

[9] BODA M.: Az alapvető katonai erények mibenléte és helye a hosszú 19. század magyar hadtudományában 2. rész - A bátorság. Hadtudomány, 282 (2018), 18-29. 